\title{
Initial steps in the degradation of benzene sulfonic acid, 4-toluene sulfonic acids, and orthanilic acid in Alcaligenes sp. strain 0-1
}

\author{
Thomas Thurnheer, ${ }^{1}$ Daniel Zürrer, ${ }^{1}$ Otmar Höglinger, ${ }^{1}$ Thomas Leisinger ${ }^{1}$ \& Alasdair M. Cook ${ }^{1,2, ~ * ~}$ \\ ${ }^{1}$ Microbiology Institute, Swiss Federal Institute of Technology, ETH-Zentrum, CH-8092 Zürich, \\ Switzerland; ${ }^{2}$ Division of Biosphere Sciences, King's College London, London W8 7AH, UK \\ $\left({ }^{*}\right.$ requests for offprints)
}

Key words: catechol from benzene sulfonate, desulfonation and dioxygenation, dioxygenase and desulfonation, quantification of cell-free desulfonation, transport of aromatic sulfonates

\begin{abstract}
Alcaligenes sp. strain O-1 grew with benzene sulfonate (BS) as sole carbon source for growth with either $\mathrm{NH}_{4}{ }^{+}$or $\mathrm{NH}_{4}^{+}$plus orthanilate (2-aminobenzene sulfonate, OS) as the source(s) of nitrogen. The intracellular desulfonative enzyme did not degrade 3- or 4-aminobenzene sulfonates in the medium, although the enzyme in cell extracts degraded these compounds. We deduce the presence of a selective permeability barrier to sulfonates and conclude that the first step in sulfonate metabolism is transport into the cell. Cell-free desulfonation of BS in standard reaction mixtures required $2 \mathrm{~mol}$ of $\mathrm{O}_{2}$ per mol. One mol of $\mathrm{O}_{2}$ was required for a catechol 2,3-dioxygenase. When meta ring cleavage was inhibited with 3-chlorocatechol in desalted extracts, about 1 mol each of $\mathrm{O}_{2}$ and of $\mathrm{NAD}(\mathrm{P}) \mathrm{H}$ per mol of $\mathrm{BS}$ were required for the reaction, and $\mathrm{SO}_{3}{ }^{2-}$ and catechol were recovered in high yield. Catechol was shown to be formed by dioxygenation in an experiment involving ${ }^{18} \mathrm{O}_{2}$. 4-Toluene sulfonate was subject to $\mathrm{NAD}(\mathrm{P}) \mathrm{H}$-dependent dioxygenation to yield $\mathrm{SO}_{3}{ }^{2-}$ and 4-methylcatechol, which was subject to meta cleavage. OS also required $2 \mathrm{~mol}$ of $\mathrm{O}_{2}$ per mol and $\mathrm{NAD}(\mathrm{P}) \mathrm{H}$ for degradation, and $\mathrm{SO}_{3}{ }^{2-}$ and $\mathrm{NH}_{4}{ }^{+}$were recovered quantitatively. Inhibition of ring cleavage with 3-chlorocatechol reduced the oxygen requirement to $1 \mathrm{~mol}$ per mol of OS $\mathrm{SO}_{3}{ }^{2-}(1 \mathrm{~mol})$ and an unidentified organic intermediate, but no $\mathrm{NH}_{4}^{+}$, were observed.
\end{abstract}

\section{Introduction}

Several naphthalene sulfonates (Brilon et al. 1981b; Nörtemann et al. 1986; Wittich et al. 1988) and benzene sulfonates (Feigel \& Knackmuss 1988; Locher et al. 1989b; Thurnheer et al. 1986, 1988) are totally degraded as sole or mixed carbon sources in pure and in defined mixed cultures of bacteria. Wider ranges of compounds can be desulfonated by bacteria (Zürrer et al. 1987) and possibly by algae (Luther \& Soeder 1987). Two groups of degradative pathways can be distinguished: firsly, those with desulfonation as the first (or sole) catabolic reaction (Brilon et al. 1981a; Luther \& Soeder 1987; Nörtemann et al. 1986; Swisher 1987; Zürrer et al. 1987; cf. Wittich et al. 1988), and secondly, those with reactions prior to desulfonation (Feigel \& Knackmuss 1988; Locher et al. 1989b; cf. Wittich et al. 1988). Nevertheless, very little is known about desulfonation reactions, and only two workers have obtained desulfonation rates above the trace level of 1 to $10 \mu$ kat per $\mathrm{kg}$ of protein in cell-free systems (Locher et al. 1989b; Thurnheer et al. 1986). One of the latter cases involves the 
degradation of benzene sulfonate (BS), 4-toluene sulfonate (TS) and the dyestuff precursor, orthanilate (OS; 2-aminobenzene sulfonate) in Alcaligenes sp. strain O-1 (Thurnheer et al. 1986). Furthermore, the transport of these compounds has received little attention (cf. Leidner et al. 1980), though one may anticipate transport systems for these highly polar compounds, and a transport system for a sulfate ester has been reported (Reinert \& Marzluf 1974).

We now report evidence for a selective permeability barrier to some aromatic sulfonates in $\mathrm{Alca}$ ligenes sp. strain O-1, for cell-free dioxygenation and desulfonation as the first metabolic reaction of $\mathrm{BS}, \mathrm{TS}$ and OS, and for meta ring cleavage.

\section{Materials and methods}

\section{Materials}

The sources of the aromatic sulfonates were given elsewhere (Thurnheer et al. 1986). Benzene dihydrodiol was a gift from Prof. D.T. Gibson. 3Chlorocatechol was kindly provided by Prof. W. Reineke. 3-Aminoveratrol was a present from Prof. H.-J. Knackmuss. 4-Nitrocatechol was from Fluka (Buchs, Switzerland); other chemicals were of the highest purity available commercially. Sephadex G-25 in PD-10 columns (Pharmacia, Upp-sala, Sweden) was used.

\section{Apparatus and analyses}

Spectrophotometric and optical density measurements (Thurnheer et al. 1986), reversed phase HPLC (Grossenbacher et al. 1986; Locher et al. 1989b), oxygen uptake measurements (Locher et al. 1989b; Zamanian \& Mason 1987), capillary GC and GC-MS (Locher et al. 1989b) were done with apparatus described previously. Protein in whole cells or in extracts was measured by Lowry-type assays, and routine colourimetric tests were used for sulfate (Johnston et al. 1975) and sulfite (Grant 1947; Kondo et al. 1982).
Organisms, growth medium and enzyme assays

Most experiments were done with Alcaligenes sp. strain O-1 (Thurnheer et al. 1986; Thurnheer et al. 1988); the taxanomy of the organism is discussed elsewhere (Jahnke et al. 1990). Pseudomonas puti$d a$ strains $\mathrm{mt} 2$ (ATCC 23793), F1 and G7 were used; the latter were kindly provided by Profs. D.T. Gibson and H.-J. Knackmuss, respectively. Defined salts-medium (Thurnheer et al. 1986) was used for growth of all organisms. Cultures were harvested in the late exponential phase, washed twice and stored frozen (Thurnheer et al. 1986). Experiments with cells in suspension were done at $5 \mathrm{mg}$ of cell-protein per ml. Suspensions of cells were disrupted in a French pressure cell and the supernatant fluid after centrifugation was used for analyses (Thurnheer et al. 1986).

The optimized assay for desulfonation of OS in orthanilate-grown cells was routinely done at $30^{\circ} \mathrm{C}$ in $5 \mathrm{ml}$ reaction mixtures (initial volume), from which samples were taken at intervals for the determination of organic and inorganic compounds. The mixture contained $250 \mu \mathrm{mol}$ Tris- $\mathrm{HCl}$ buffer, $\mathrm{pH} 7.2,7.5 \mu \mathrm{mol} \mathrm{OS}, 0.75 \mu \mathrm{mol} \mathrm{NADH}$ and $30 \mathrm{mg}$ of protein, with which the reaction was started. Most experiments in the oxygen electrode were done with $5 \mathrm{ml}$ reaction mixtures and were started by the addition of $0.25 \mu \mathrm{mol}$ of aromatic substrate. Some work was done in $1 \mathrm{ml}$ reaction mixtures (cf. Zamanian \& Mason 1987) which contained $50 \mu \mathrm{mol}$ Tris- $\mathrm{HCl}$ buffer, $\mathrm{pH} 7.5,2 \mathrm{mg}$ of protein, 1 to $3 \mathrm{nmol} 3$-chlorocatechol, $250 \mathrm{nmol}$ sulfonoaromatic substrate and was started by additions of $20 \mathrm{nmol}$ of $\mathrm{NADH}$; the additions of chlorocatechol were just enough to titrate out the activity of catechol 2,3-dioxygenase, which allowed the $\mathrm{NAD}(\mathrm{P}) \mathrm{H}$ requirement of the desulfonation reaction to be measured when desalted extract was used.

Experiments with ${ }^{18} \mathrm{O}_{2}$ were done at $30^{\circ} \mathrm{C}$ in $10-\mathrm{ml}$ reaction mixtures contained in $125 \mathrm{ml}$ flasks which were gassed with nitrogen, evacuated and filled with mixtures of nitrogen and isotopes of oxygen (cf. Locher et al. 1989b). The reaction mixtures contained $450 \mu \mathrm{mol}$ potassium phosphate 
buffer, $\mathrm{pH} 7.2$, whole cells (60 mg of protein), $20 \mu \mathrm{mol}$ of 3 -chlorocatechol, and $30 \mu \mathrm{mol}$ of BS, with which the reaction was started. The reaction was monitored by HPLC, and when BS was exhausted, cells were removed by centrifugation $\left(30,000 \mathrm{~g}, 20 \mathrm{~min}, 4^{\circ} \mathrm{C}\right)$ and catechol was extracted from the supernatant fluid in two 5 - $\mathrm{ml}$ portions of diethyl ether, which was evaporated off. The residual material was dissolved in $0.5 \mathrm{ml}$ of methanol and examined directly by GC and GC-MS (Locher et al. 1989b).

Catechol 1,2-dioxygenase (Hegemann 1966), catechol 2,3-dioxygenase (and 4-methylcatechol 2,3-dioxygenase) (Cain \& Farr 1968), cis, cis muconate lactonizing enzyme (Hegemann 1966), 2-hydroxymuconate semialdehyde hydrolase and 4-oxalcrotonate dehydrogenase (Sala-Trepat \& Evans 1971) were assayed by standard methods. The behaviour of protocatechuate and other compounds in crude extract was followed by HPLC, analogous to the assay for desulfonation of OS.

\section{Synthesis of 3- and 4-aminocatechol}

Catechol was acetylated to 1-O-acetylcatechol, which was nitrated (Schulz \& Hecker 1973). Products $(10 \mathrm{~g})$ were applied to a column $(60 \mathrm{by} 8 \mathrm{~cm})$ of silica gel (60-80 mesh) and 3-nitro-1-O-acetylcatechol $(500 \mathrm{mg})$ was eluted with a mixture of hexane and ether $(2: 1 \mathrm{v} / \mathrm{v})$ as the first of many products. This intermediate was converted to 3-nitrocatechol ( $81 \%$ yield), which was reduced to 3-aminocatechol hydrochloride (39\% yield) (Schulz \& Hecker 1973), whose identity was confirmed by ${ }^{13}$ C-NMR (147.68, 141.40, 120.65, 119.78, 116.73 and 114.88). 4-Nitrocatechol was reduced to 4-aminocatechol, whose identity was confirmed by ${ }^{13}$ C-NMR (149.65, 149.15, 125.06, 118.71, 116.77 and 113.01).

\section{Results}

Selective permeability of the cell membrane for sulfonates

Strain O-1 can utilize only three benzene sulfonates for growth (BS, TS and OS), whereas cell extracts can desulfonate at least seven substrates (Thurnheer et al. 1986), so we suspected that there was selective permeability of the cell membrane towards benzene sulfonates. This idea was supported when non-growing suspensions of cells from BSsalts medium failed to desulfonate the four nongrowth substrates for the enzyme (4-hydroxybenzene sulfonate, 4-sulfobenzoate, metanilate [3aminobenzene sulfonate] and sulfanilate [4-aminobenzene sulfonate], each of $6 \mathrm{mM}$ ). Cultures of strain $\mathrm{O}-1$ were then grown in N-limited BS-salts medium containing different potential $\mathrm{N}$-sources. The enzyme(s) catalyzing desulfonation were thus present, and growth, shown here as substrate disappearance, was rapid if $2 \mathrm{mM}$ ammonium ion was the source of nitrogen (Fig. 1a). Growth was equally rapid if $50 \%$ of the ammonium ion was replaced by OS, which also disappeared (Fig. 1b), and which was utilized for growth. If orthanilate was replaced by sulfanilate or metanilate (Fig. 1c, d), the latter compounds were not desulfonated, though the intracellular enzyme was active on BS for at least eight days. We presume that the cell membrane of strain O-1 is impermeable to aromatic sulfonates and contains one or more transport systems, each specific for three or less aromatic sulfonates.

\section{Desulfonation of benzene sulfonate and p-toluene sulfonate, and ring cleavage of the reaction products}

Conditions for the desulfonation of BS in extracts of OS-grown cells were optimized for substrate, cofactor and buffer concentrations, for temperature, $\mathrm{pH}$ and for the nature of the buffer (not shown). A specific rate of about $160 \mu \mathrm{kat}$ per $\mathrm{kg}$ of protein was obtained (at $5 \mathrm{mg}$ of protein per $\mathrm{ml}$ of reaction mixture), whether measured as substrate 

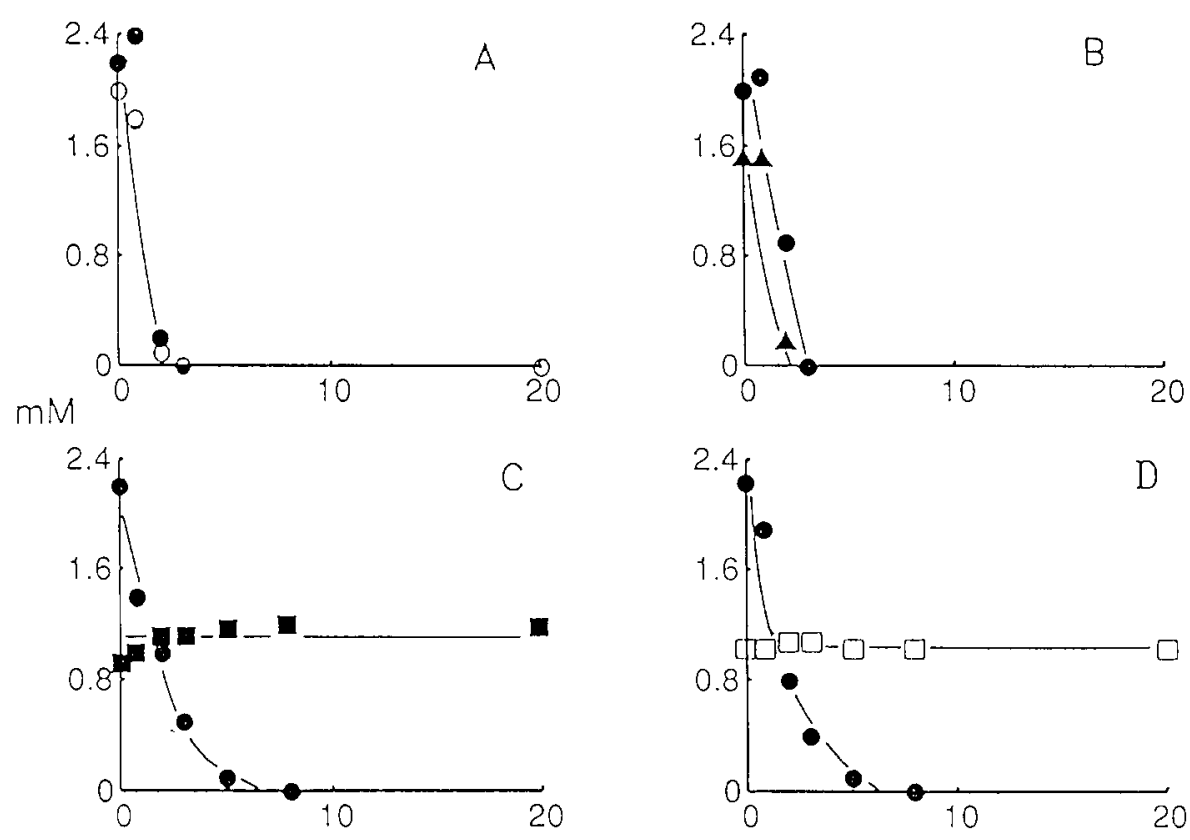

Days

Fig. 1. Concentrations of benzene sulfonate(s) and the nitrogen source(s) in cultures of Alcaligenes sp. strain O-1 growing in nitrogen-limited BS-salts medium containing different potential sources of additional nitrogen. The organism was pregrown in BS-salts medium and growing cells were washed in nitrogen-free salts-medium and used as inoculum (1\% v/v) for these experiments. BS (O), OS $(\boldsymbol{A})$, metanilate $(\boldsymbol{D})$ and sulfanilate $(\square)$ were present where shown; ammonium $(\bigcirc)$ was present in each reaction, but was degraded within two days in each case and is usually not shown because so many data points overlap.

disappearance or sulfite release, some fourfold higher than non-optimized rates (cf. Thurnheer et al. 1986). Desulfonation showed an absolute requirement for molecular oxygen (Thurnheer et al. 1986). Allowing $1 \mathrm{~mol}$ of $\mathrm{O}_{2}$ per mol for ring cleavage (see below), 1 mol of $\mathrm{O}_{2}$ was consumed per mol of BS desulfonated (Table 1, 'Uptake of $\mathrm{O}_{2}$ ); left hand column). Desulfonation also showed an absolute requirement for $\mathrm{NAD}(\mathrm{P}) \mathrm{H}$ : $\mathrm{NADH}$ was used routinely in reaction mixtures because the rate was some twofold higher than with NADPH. NADH was required in catalytic amounts only, so an efficient recycling of NADH must be available in the system.

No organic products from BS were observed in the standard reaction mixtures, but we presumed catechol to be involved because of the very high levels of catechol 2,3-cleavage induced under these conditions (22-fold higher than the desulfonation; Table 1). The possibility that benzene dihydrodiol might be involved as an intermediate in the degradation of BS was rendered unlikely, because this dihydrodiol was not transformed by strain $\mathrm{O}-1$ whereas a high oxidation rate was observed with $P$. putida $\mathrm{F} 1$ grown in benzene-salts medium. We were unable selectively to inhibit ring cleavage with $\alpha, \alpha^{\prime}$-dipyridyl, $\mathrm{H}_{2} \mathrm{O}_{2}$, o-nitrophenol, $o$ - or $m$-phenathroline or pyridine, but attained non-reversible inhibition with 3-chlorocatechol (cf. Bartels et al. 1984; Klecka \& Gibson 1981). We thus had preliminary evidence for suicide inactivation of a catechol 2,3-dioxygenase, and we used this effect to study the desulfonation in the absence of the subsequent metabolic reactions.

$\mathrm{BS}$, in reaction mixtures containing 3-chlorocatechol, was converted to a compound which cochromatographed (HPLC) with authentic catechol, and whose identity as catechol was confirmed by its spectral properties (Table 2 ), by co-chromatography (GC) with authentic material and by GC- 
MS (see below). The yield of product was $90-95 \%$, and under these conditions only $1 \mathrm{~mol}$ of $\mathrm{O}_{2}$ per mol of BS was consumed (Table 1). Concomitantly, 1 mol of sulfite per mol of BS was released. The stoichiometry of the requirement for NADH had to be examined in desalted extract, because small molecules in crude extract sufficed to allow transformation of about $1 \mathrm{mM}$ OS to sulfite. Desalted extract containing inhibited catechol 2,3-dioxygenase and an excess of BS utilized about $0.8 \mathrm{~mol}$ of $\mathrm{O}_{2}$ per mol of NADH. Our data indicate that, during desulfonation, $1 \mathrm{~mol}$ each of $\mathrm{BS}, \mathrm{O}_{2}$, and $\mathrm{NAD}(\mathrm{P}) \mathrm{H}$ are converted to $1 \mathrm{~mol}$ each of sulfite, catechol and $\operatorname{NAD}(\mathrm{P})^{+}$.

The catechol produced from $\mathrm{BS}$ in the presence of ${ }^{16} \mathrm{O}_{2}$ or ${ }^{16} \mathrm{O}_{2}+{ }^{18} \mathrm{O}_{2}$ was examined by GC-MS. In the presence of ${ }^{16} \mathrm{O}_{2}$, a molecular ion of $\mathrm{m} / \mathrm{z}=110$ was observed, and the fragmentation pattern $\left(\mathrm{M}^{+}-\mathrm{H}_{2} \mathrm{O}, \mathrm{M}^{+}-\mathrm{CHO}, \mathrm{M}^{+}-\mathrm{H}_{2} \mathrm{O}-\mathrm{CO}\right.$, $\mathrm{M}^{+}-\mathrm{CHO}-\mathrm{CO}$ ) confirmed the identity of the catechol. When the mixture of isotopes was used, two molecular ions were observed, at 110 and 114 . There was no significant peak at 112 . These data confirm that desulfonation is catalyzed by dioxygenation.

Degradation of catechol had an absolute requirement for stoichiometric amounts of molecular oxygen ( $1 \mathrm{~mol}$ per mol of catechol; Table 1 ). The product was yellow (near $\mathrm{pH} 7$ ) and co-chromatographed (HPLC) with, and was spectrally identical to authentic 2-hydroxymuconate semialdehyde (Table 2). No ortho cleavage or cis, cis-muconate lactonizing enzyme was observed (Table 1), though we could assay both activities in $P$. putida G7. 2-Hydroxymuconate semialdehyde was subject to a low rate of transformation in desalted extracts of strain O-1 (Table 1), but was degraded much more rapidly on the addition of $\mathrm{NAD}^{+}$(Table 1$)$. We interpret these data as low activity of a 2-hydroxymuconate semialdehyde hydrolase and higher activity of 4-oxalcrotonate dehydrogenase and that the latter is the source of NADH for continued rapid desulfonation in the presence of sub-stoichiometric amounts of NADH (see above). Strain O-1 thus catalyzes meta ring cleavage of catechol, which is degraded largely by the oxalcrotonate branch of the meta pathway.

Table 1. Specific activities of selected enzymes in, and oxygen uptake by, extracts of Alcaligenes sp. strain O-1 grown in orthanilate-salts medium.

\begin{tabular}{|c|c|c|c|c|}
\hline \multirow[t]{3}{*}{ Substrate } & \multirow[t]{3}{*}{ Enzyme reaction } & \multirow{3}{*}{$\begin{array}{l}\text { Specific activity } \\
\text { in cell extracts } \\
\text { ( } \mu \mathrm{kat} \mathrm{kg}^{-1} \\
\text { of protein) }\end{array}$} & \multicolumn{2}{|c|}{ Uptake of $\mathrm{O}_{2}{ }^{a}\left(\mathrm{~mol} \mathrm{~mol}^{-1}\right.$ substrate $)$} \\
\hline & & & \multicolumn{2}{|c|}{ 3-Chlorocatechol } \\
\hline & & & absent & present \\
\hline Benzene sulfonate & Desulfonation & 160 & 2.1 & 1.0 \\
\hline$p$-Toluene sulfonate & Desulfonation & 90 & 2.2 & 1.0 \\
\hline Orthanilate & Desulfonation & 160 & 1.9 & 1.0 \\
\hline Benzene dihydrodiol $^{b}$ & Dehydrogenase & $<10$ & & \\
\hline Catechol & 2,3-Dioxygenase & 3600 & 1.0 & 0.0 \\
\hline \multirow[t]{2}{*}{ 2-Hydroxymuconate semialdehyde } & Hydrolase & 80 & $\mathrm{na}^{c}$ & na \\
\hline & Dehydrogenase & 220 & na & na \\
\hline Catechol & 1,2-Dioxygenase ${ }^{d}$ & $<10$ & na & na \\
\hline cis,cis-muconate & Lactonization & $<10$ & na & na \\
\hline 4-Methyl-catechol & 2,3-Dioxygenase & 4800 & 1.0 & 0.0 \\
\hline
\end{tabular}

\footnotetext{
${ }^{a}$ These data are from extracts of OS-grown cells, but the same values were observed with extracts from BS-grown cells. Extracts of TS-grown cells displayed a very high rate of endogenous respiration and were not used. The data represent the mean of 3 values; SD $6 \%$. ${ }^{b}$ This activity was measured in whole cells only.

${ }^{c}$ na: no assay

${ }^{d}$ This activity was tested when the meta enzyme was inhibited. In the absence of inhibitor (3-chlorocatechol) an artefact due to the overlap of the UV-spectra of the semialdehyde product of meta cleavage, and of the muconate product of ortho cleavage, led to the apparent presence of the catechol-1,2-dioxygenase.
} 
Strain O-1 degraded benzoate via 2-hydroxymuconate semialdehyde, which was identified as described in the previous paragraph. In contrast to work with desulfonation, however, it was very difficult to obtain the catechol 2,3-dioxygenase from benzoate-grown cells in cell-free extract, where this enzyme activity was unstable. We presume there to be isofunctional catechol 2,3-dioxygenases in this organism. The presence of benzoate did not cause any detectable oxygen uptake in extracts of orthanilate-grown cells, whereas sulfonates were readily oxygenated. Benzoate was thus not a substrate for the desulfonation system. In contrast, naphthalene carboxylate is a substrate for cells of Pseudomonas sp. strain A3 able to desulfonate naphthalene sulfonates (Brilon et al. 1981b).
The degradation of TS was analogous to that of BS. $1 \mathrm{~mol}$ each of TS, NAD(P)H and $\mathrm{O}_{2}$ were converted to about $1 \mathrm{~mol}$ each of 4-methylcatechol (Table 2), sulfite and, presumably, $\mathrm{NAD}(\mathrm{P})^{+}$. Methylcatechol was subject to meta ring cleavage (Table 2) and the semialdehyde was presumably degraded largely via a methyl-oxalcrotonate. No protocatechuate dioxygenase was observed, so we presume all methylcatechol to be degraded directly via meta ring cleavage.

All experiments in this section were done with cell extracts, unless otherwise indicated (Table 1). These experiments were repeated with whole cells (data not shown), which differed from cell extracts only in releasing the sulfonate moiety as the sulfate and not the sulfite ion.

Table 2. Data from the UV-spectra of substrates and intermediates observed during degradation of aromatic sulfonates by Alcaligenes sp. strain O-1. Compounds in reaction mixtures were separated by reversed-phase HPLC (i.e. the most polar first) with $100 \mathrm{mM}$ potassium phosphate, $\mathrm{pH} 2.2$, as the mobile phase (unless otherwise stated) and the spectra were recorded with a diode array detector.

\begin{tabular}{|c|c|c|c|c|c|c|c|c|}
\hline \multirow[t]{2}{*}{ Substance } & \multirow{2}{*}{$\begin{array}{l}\mathrm{T}_{\mathrm{R}}{ }^{a} \\
(\mathrm{~min})\end{array}$} & \multicolumn{7}{|c|}{ Data from UV-spectra $(\mathrm{nm})^{b}$} \\
\hline & & $\max$ & $\min$ & $\max$ & $\min$ & $\max$ & $\min$ & $\max$ \\
\hline Benzene sulfonate & 16.9 & 193 & 202 & 211 & & & & \\
\hline cis-Benzene dihydrodiol & $>30$ & 199 & 225 & & & 259 & & \\
\hline Catechol $(\mathbf{A})^{c}$ & $>30$ & 189 & & $217 \mathrm{~s}$ & 245 & 276 & & \\
\hline Catechol $(\mathbf{B})^{d}$ & $>30$ & 189 & & $217 \mathrm{~s}$ & 245 & 276 & & \\
\hline 2-Hydroxymuconate semialdehyde (A) & 5.6 & 200 & 212 & 220 & & & 292 & 374 \\
\hline 2-Hydroxymuconate semialdehyde $(\mathrm{B})^{e}$ & 5.6 & 200 & 212 & 220 & & & 292 & 374 \\
\hline$p$-Toluene sulfonate & $>30$ & 196 & 206 & 220 & & & & \\
\hline 4-Methylcatechol (A) & $>30$ & 200 & & & 240 & 280 & & \\
\hline 4-Methylcatechol (B) & $>30$ & 200 & & & 240 & 280 & & \\
\hline 2-Hydroxy-methyl-muconate semialdehyde $(\mathrm{A})^{e}$ & 9.0 & 205 & & & & & 300 & 383 \\
\hline 2-Hydroxy-methyl-muconate semialdehyde $(B)^{e}$ & 9.0 & 205 & & & & & 300 & 383 \\
\hline Orthanilate & 9.4 & 193 & 199 & 203 & 226 & 237 & 263 & 298 \\
\hline Desulfonated orthanilate (B) & 8.9 & 200 & & $224 s$ & 236 & 286 & & \\
\hline 3-Aminocatechol (A) & 4.6 & 202 & & $216 \mathrm{~s}$ & 243 & 272 & & \\
\hline 4-Aminocatechol (A) & 4.1 & 197 & & $214 s$ & 245 & 276 & & \\
\hline 1,2,3-Trihydroxy-benzene (A) & 13.2 & 199 & & $223 \mathrm{~s}$ & & & & \\
\hline 1,2,4-Trihydroxy-benzene (A) & 9.9 & 195 & & $224 s$ & 236 & 288 & & \\
\hline 4-Aminoresorcinol (A) & 4.8 & 197 & & $216 s$ & 241 & 273 & & \\
\hline 2-Aminophenol (A) & 7.3 & 192 & 202 & 213 & 235 & 269 & & \\
\hline 3-Aminophenol (A) & 6.2 & 192 & 205 & 215 & 238 & 270 & & \\
\hline
\end{tabular}

\footnotetext{
${ }^{a}$ Values over $30 \mathrm{~min}$ are less accurate and were used here only to facilitate comparisons of UV-spectra; routine determinations involved isocratic conditions with methanol in the mobile phase or gradient elutions.

${ }^{b}$ The value in italics represents the highest molar absorbance. The use of the addendum ' $\mathrm{s}$ ' indicates a shoulder.

${ }^{c} \mathrm{~A}$, Authentic material.

${ }^{d} \mathrm{~B}$, Biological product in an enzyme preparation: catechol was derived from BS, methylcatechol from TS and the semialdehydes from the appropriate catechol.

${ }^{e}$ In this case the mobile phase was $10 \mathrm{mM}$ potassium phosphate buffer, $\mathrm{pH} 6.7$.
} 
Desulfonation of orthanilate and ring cleavage of the reaction product

The rate of desulfonation of OS in extracts of OSgrown cells was about $160 \mu \mathrm{kat}$ per $\mathrm{kg}$ of protein, under our standard conditions, whether measured as substrate disappearance, sulfite ion formation or release of ammonium ion, and was thus some $23 \%$ of the rate observed in growing cells $(0.7 \mathrm{mkat} / \mathrm{kg}$ of protein; Thurnheer et al. 1986). In contrast to the behaviour of e.g., catechol 2,3-dioxygenase (Fig. 2, inset), the specific activity of the desulfonative enzyme(s) was not independent of the protein concentration when the standard assay was used (Fig. 2). This observation was confirmed with data from an oxygen electrode, which was a more sensitive assay and showed a higher specific activity such that, at about $4 \mathrm{mg}$ of protein $\mathrm{ml}^{-1}$, the same specific activity was obtained in cell extracts as was required in growing cells. The low or zero activity at low protein concentration suggests a multi-component system typical of a ring-activating dioxygenase (Gibson et al. 1982; Mason 1988). Desulfonation in the extract required $2 \mathrm{~mol}$ of $\mathrm{O}_{2}$ per mol of OS (Table 1) and $\mathrm{NAD}(\mathrm{P}) \mathrm{H}$ in the standard reaction mixture, and no organic intermediates were observed.

3-Chlorocatechol prevented further metabolism of the product from the initial attack on OS, which required $1 \mathrm{~mol}$ of $\mathrm{O}_{2}$ (Table 1 ) and about $1.2 \mathrm{~mol}$ of NAD(P)H per mol of OS. This attack was a desulfonation and the sulfonate moiety was recovered as sulfate from whole cells, whereas no ammonium ion was released (Fig. 3). An organic product was released from OS (Table 2), and it chromatographed close to the educt, OS, which suggested that an ionized group (i.e., the amino group) was still present after dioxygenation and cleavage of the C-S bond. We thus presume the metabolism of OS to involve initial dioxygenation followed by meta ring cleavage.

The unidentified product was unstable. It turned brown within minutes at $\mathrm{pH} 7.5$ and within $6 \mathrm{~h}$ at $\mathrm{pH} 6.9$; it was stable at $4^{\circ} \mathrm{C}$ in $100 \mathrm{mM}$ potassium phosphate buffer, $\mathrm{pH} 2$. The compound was degraded (at pH 6.9 and in the absence of 3-chlorocatechol) within $5 \mathrm{~min}$ by cell-free extracts of strain

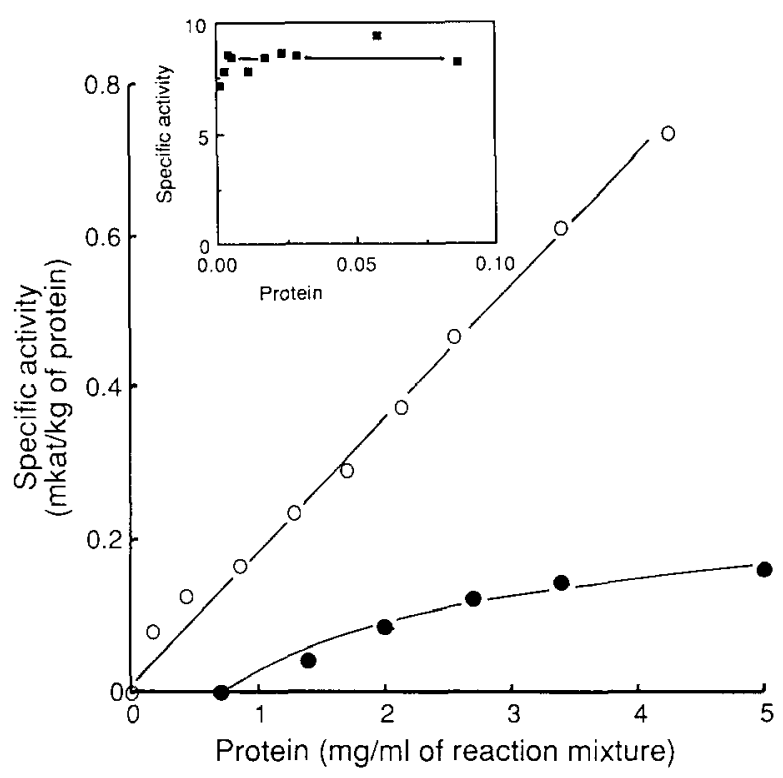

Fig. 2.Desulfonation of orthanilate and meta dioxygenation of catechol in extracts of orthanilate-grown cells of Alcaligenes sp. strain $\mathrm{O}-1$ as a function of protein concentration. Crude extracts of OS-grown strain O-1 were prepared and reaction mixtures were set up with different protein concentrations. The reaction rate at $30^{\circ} \mathrm{C}$ was calculated from the rate of release of sulfite ion in $5 \mathrm{ml}$ reaction mixtures $(\Theta)$, as oxygen uptake in $1 \mathrm{ml}$ reaction mixtures $(O)$, or, for catechol 2,3-dioxygenase, from product formation ( $\square$ ). Net oxygen uptake, corrected for endogenous reactions, was considered to represent desulfonation and ring cleavage, and rates of desulfonation were taken as $50 \%$ of the net rate of oxygen uptake. The axes for the inset have the same units as the major graph.

O-1 grown in OS-salts medium; as with OS as substrate, no yellow colour (a hydroxymuconate semialdehyde) was observed by eye, in contrast to the reaction with BS and TS. The unknown was not degraded by extracts from succinate-grown cells. The unknown was thus an intermediate in the degradative pathway of OS, or readily converted to an intermediate, and the product of putative ring cleavage was not 2-hydroxymuconate semialdehyde but possibly an aminated derivative thereof. We have been unable to isolate or identify the unknown compound, but is neither 3-or 4-aminocatechol, or several other putative products (Table 2). 

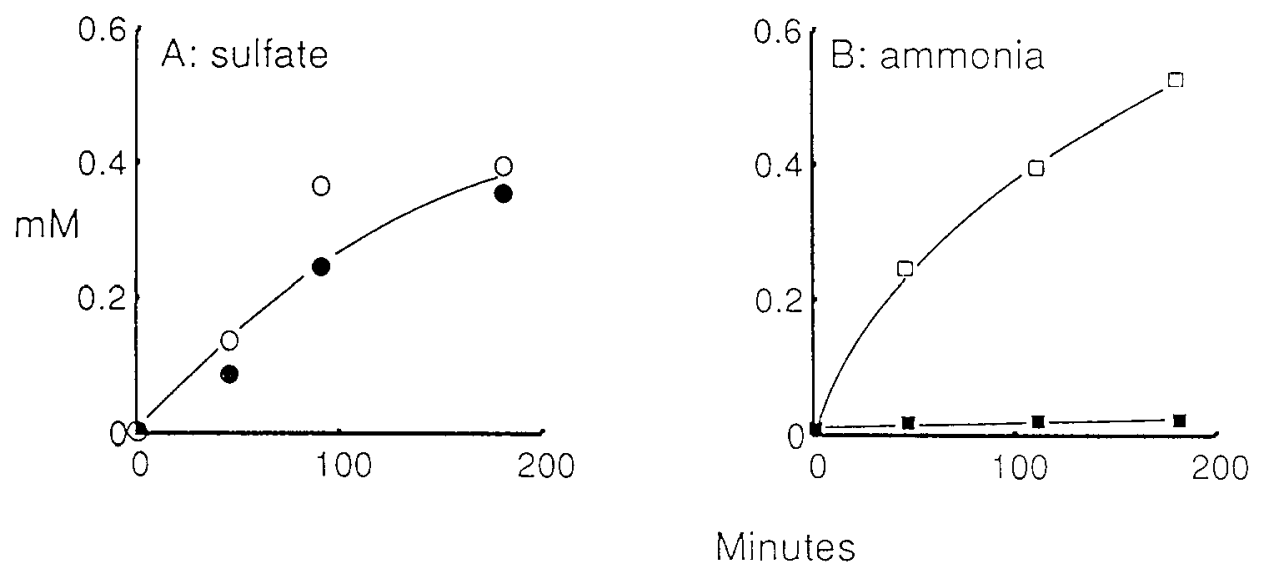

Fig. 3. Effect of 3-chlorocatechol on the release of the sulfonate and amino groups from orthanilate by orthanilate-grown cells of Alcaligenes sp. strain O-1. The organism was harvested from $6 \mathrm{mM}$ OS-salts medium during growth. Cells were washed, suspended to $100 \mathrm{mg}$ wet wt. of cells per $\mathrm{ml}$ in $50 \mathrm{mM}$ potassium phosphate buffer, $\mathrm{pH} 7.2$, equilibrated to $30^{\circ} \mathrm{C}$ for 15 min with or without $2 \mathrm{mM}$ 3-chlorocatechol, and reactioons were started by the addition of orthanilate to $0.5 \mathrm{mM}(\mathrm{A})$ or $1 \mathrm{mM}$ (B). The data are corrected for basal levels of release of sulfate ion $(0.02 \mathrm{mM}$ in $180 \mathrm{~min})$ or ammonium ion $(0.4 \mathrm{mM}$ in $180 \mathrm{~min})$ from cells in the absence of orthanilate: the presence of 3-chlorocatechol had no effect on the release of ammonium in control experiments with strain O-1. Open symbols, no inhibitor present; filled symbols, $2 \mathrm{mM} 3$-chlorocatechol present to inhibit ring cleavage.

\section{Discussion}

The data illustrate that transport is the first specific step in the degradation of BS, TS or OS by Alcaligenes sp. strain O-1. The first metabolic reaction is desulfonation, in contrast to a later desulfonation in the degradation of TS in Comamonastestosteroni T-2 (discussed in Locher et al. 1989b).

Our data on the desulfonation of BS demonstrate the involvement of dioxygenation in desulfonation; these quantitative data are analogous to, and augment our work with 4-sulfobenzoate dioxygenase (Locher et al. 1989b), and they confirm quantitatively a mechanism indicated by Cain \& Farr (1968). Our evidence argues against a desulfonated dihydrodiol intermediate (Table 1), with corresponding regeneration of NADH during oxidation to catechol. Rather the data support a mechanism whereby a sulfodihydrodiol (Fig. 4) formed on dioxygenation is degraded to yield the catechol without an NAD-linked oxidation (Brilon et al. 1981b). It is as yet unclear whether the putative intermediate exists only at the catalytic centre of the dioxygenase, is desulfonated by a separate protein or decays spontaneously. The nature of the degradation of OS is still unclear. In contrast to the initial deamination of 4-aminobenzene sulfonate to 4-sulfocatechol in a two-member consortium and in a pure culture (Feigel \& Knackmuss 1988; Locher et al. 1989a; Locher et al. 1989b), we observed initial oxygenation and desulfonation of OS in strain O-1 (Fig. 3, Table 1) yielding sulfite and an unidentified organic intermediate.

The data reconfirm that the sulfonate moiety of a sulfonoaromatic is released as sulfite on cleavage of the aromatic C-S bond (cf. Johnston et al. 1975). The uncertainty of data derived from whole cells is emphasized, because growing cells of strain $\mathrm{O}-1$ excrete large amounts of sulfite from sulfonates (Thurnheer et al. 1986), whereas the cell suspensions in this study release only sulfate.

We hypothesize that the desulfonation is a multicomponent enzyme, because of the kinetics we observe (Fig. 2). This corresponds to preliminary data from a partial purification of the desulfonative enzyme complex for BS in another bacterium (Kondo et al. 1982). The idea is analogous to the suggestion of Brilon et al. (1981a), that the desulfonation of naphthalene sulfonate is carried out by a mutant naphthalene dioxygenase with a wide substrate specificity; naphthalene dioxygenase is a multi-component system (Haigler \& Gibson 1990). 


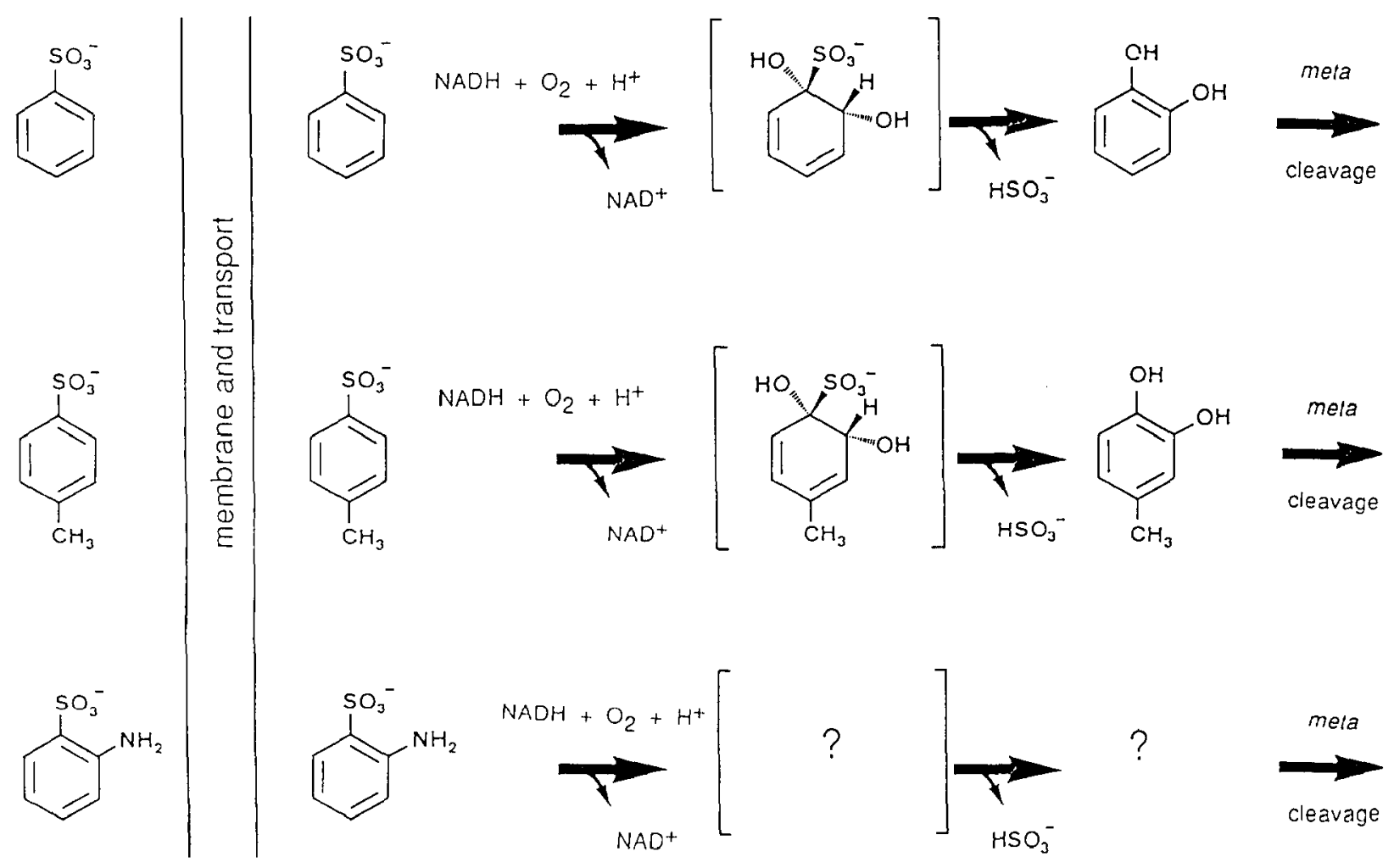

Fig. 4. Initial steps in the degradation of BS, TS and OS in Alcaligenes sp. strain O-1. The structures in square brackets are hypothetical intermediates.

A claim for a single-component desufonative enzyme seems to have been made (Stavskaya et al. 1987). The enzyme reaction was not defined, and an unverified, indirect assay was used which involved boiling the extract prior to a sulfite assay. We find boiling to destroy sulfite and wonder whether a non-specific sulfite assay detected a protein degradation product.

The term 'specific activity' has been used in this paper, but it is clear from Fig. 2 that it is being used incorrectly, because one basic requirement for this term is not met, namely independence of protein concentration. This observation complicates comparisons amongst different papers on multi-component dioxygenases, or even amongst different preparations of one enzyme system.

Strain O-1 apparently degrades its sulfonated substrates by only one pathway. Thus catechol is degraded via the meta pathway and not by the ortho pathway (Table 1), and the methylcatechol is de- graded by meta cleavage and not through conversion to protocatechuate. However, the organism does seem to contain isofunctional enzymes for some reactions, e.g., the catechol 2,3-dioxygenases observed during growth on BS and benzoate. We wonder how many transport systems, dioxygenases (sulfite-forming) and ring cleavage enzymes are synthesized.

\section{Acknowledgements}

We are grateful to Profs. D.T. Gibson, H.-J. Knackmuss, W. Reineke and D.W. Ribbons, and Drs. C. Joannou and J.R. Mason for gifts of chemicals and bacteria, and for advice. Dr. A. Pfaltz kindly made apparatus available, and U. Leutenegger and C. Spinner helped in or carried out the syntheses of 3- and 4-aminocatechol. We thank Stefan Wolf for techical assistance. This work was 
supported by grants from the Swiss Federal Institute of Technology, Zürich, and from the Kommission zur Förderung der wissenschaftlichen Forschung (Project 1567).

\section{References}

Bartels I, Knackmuss H-J \& Reineke W (1984) Suicide inactivation of catechol 2,3-dioxygenase from Pseudomonas putida mt-2 by 3-halocatechols. Appl. Environ. Microbiol. 47: 500505

Brilon C, Beckmann W \& Knackmuss H-J (1981) Catabolism of naphthalenesulfonic acids by Pseudomonas sp. A3 and Pseudomonas sp. C22. Appl. Environ. Microbiol. 42: 44-55

Brilon C, Beckmann W, Hellwig M \& Knackmuss H-J (1981) Enrichment and isolation of naphthalenesulfonic acid-utilizing pseudomonads. Appl. Environ. Microbiol. 42: $9-45$

Cain RB \& Farr DR (1968) Metabolism of arylsulphonates by micro-organisms. Biochem. J. 106: 859-877

Feigel B \& Knackmuss H-J (1988) Bacterial catabolism of sulfanilic acid via catechol-4-sulfonic acid. FEMS Microbiol. Lett. 55: $113-118$

Gibson DT, Yeh W, Lin T \& Subramanian V (1982) Toluene dioxygenase: a multicomponent enzyme system from Pseudomonas putida. In: Nozaki M, Yamamoto S, Ishimura Y, Coon MJ, Ernster L \& Eastbrook RR (Eds) Oxygenases and Oxygen Metabolism (pp 51-61). Academic Press, New York

Grant WM (1974) Colorimetric determination of sulphur dioxide. Anal Chem 19: 345-346

Grossenbacher H, Thurnheer T, Zürrer D \& Cook AM (1986) Determination of sulfonated azo dyestuffs and their bacterial metabolites by high pressure liquid chromatography. J. Chromatogr. 360: 219-223

Haigler BE \& Gibson DT (1990) Purification and properties of NADH-ferredoxin ${ }_{\text {NAP }}$ reductase, a component of naphthalene dioxygenase from $P$ seudomonas sp. strain NCIB 9816. J. Bacteriol. 172: 457-464

Hegemann GD (1966) Synthesis of the enzymes of the mandelate pathway by Pseudomonas putida. J. Bacteriol. 91: 11411154

Jahnke M, El-Banna T, Klintworth R \& Auling G (1990) Mineralization of orthanilic acid is a plasmid-associated trait in Alcaligenes sp. O-1. J. Gen. Microbiol. In press

Johnston JB, Murray K \& Cain RB (1975) Microbial metabolism of aryl sulphonates. A reassessment of colourimetric methods for the determination of sulphite and their use in measuring desulphonation of aryl and alkylbenzene sulphonates. Antonie van Leeuwenhoek 41: 493-511

Klecka GM \& Gibson DT (1981) Inhibition of catechol 2,3dioxygenase from Pseudomonas putida by 3-chlorocatechol. Appl. Environ. Microbiol. 41: 1159-1165

Kondo H, Yazawa M, Enami H \& Ishimoto M (1982) Sulphite production from benzenesulphonate by bacterial enzyme. (In Japanese.) Ganryu Aminosan 5: 237-242

Leidner H, Gloor R, Wüest D \& Wuhrmann K (1980) The influence of the sulfonic group on the biodegradability of $n$-alkanebenzenesulfonates. Xenobiotica 10: 47-56

Locher HH, Leisinger T \& Cook AM (1989a) Degradation of $p$-toluenesulphonic acid via sidechain oxidation, desulphonation and meta ring cleavage in Pseudomonas (Comamonas) testosteroni T-2. J. Gen. Microbiol. 135: 1969-1978

Locher HH, Thurnheer T, Leisinger T \& Cook AM (1989b) 3-Nitrobenzenesulfonic acid, 3-aminobenzenesulfonic acid and 4-aminobenzenesulfonic acid as sole carbon sources for bacteria. Appl. Environ. Microbiol. 55: 492-494

Luther M \& Soeder CJ (1987) Some naphthalenesulfonic acids as sulfur sources for the green microalga, Scenedesmus obliquus. Chemosphere 16: 1565-1578

Mason JR (1988) Oxygenase catalyzed hydroxylation of aromatic compounds: simple chemistry by complex enzymes. Int. Ind. Biotechnol. 8 (4): 19-24

Nörtemann B, Baumgarten J, Rast HG \& Knackmuss H-J (1986) Bacterial communities degrading amino-and naphthalene-2-sulfonates. Appl. Environ. Microbiol. 52: 1195-1202

Reinert WR \& Marzluf GA (1974) Regulation of sulfate metabolism in Neurospora crassa: transport and accumulation of glucose 6-sulfate. Biochem. Genet. 12: 97-108

Sala-Trepat JM \& Evans WC (1971) The meta cleavage of catechol by Azotobacter species: 4-oxalcrotonate pathway. Eur. J. Biochem. 20: 400-413

Schulz G \& Hecker E (1973) Über die Muconsäurespaltung von einfachen $o$-Diphenolen. Z. Naturforsch. 28c: 662-674

Stavskaya SS, Pavlova IN, Radchenko OS, Taranova LA, Zahkarova I \& Ya DK (1987) Purification and characteristics of the desufonative enzyme from Pseudomonas alcaligenes. Mikrobiologiya 56: 928-932

Swisher RD (1987) Surfactant Biodegradation, 2nd, ed. (pp 517-645). Marcel Dekker, New York

Thurnheer T, Cook AM \& Leisinger T (1988) Co-culture of defined bacteria to degrade seven sulfonated aromatic compounds: efficiency, rates and phenotypic variations. Appl. Microbiol. Biotechnol. 29: 605-609

Thurnheer T, Köhler T, Cook AM \& Leisinger T (1986) Orthanilic acid and analogues as carbon sources for bacteria: growth physiology and enzymic desulphonation. J. Gen. Microbiol. 132: 1215-1220

Wittich RM, Rast HG \& Knackmuss H-J (1988) Degradation of naphthalene-2,6- and naphthalene-1,6-disulfonic acid by a Moraxella sp. Appl. Environ. Microbiol. 54: 1842-1847

Zamanian M \& Mason JR (1987) Benzene dioxygenase in Pseudomonas putida: subunit composition and immuno-cross-reactivity with other aromatic dioxygenases. Biochem. J. 244: 611-616

Zürrer D, Cook AM \& Leisinger T (1987) Microbial desufonation of substituted naphthalenesulfonic acids and benzenesulfonic acids. Appl. Environ. Microbiol. 53: 1459-1463 